\title{
Classroom Adaptations for Blended Learning Practices
}

\author{
Thaisa Sampaio Sarmento \\ Faculdade de Arquitetura e \\ Urbanismo \\ Universidade Federal de Alagoas \\ Maceió Alagoas Brazil \\ thaisa.sampaio@fau.ufal.br
}

\author{
Alex Sandro Gomes \\ Centro de Informática \\ Universidade Federal de \\ Pernambuco \\ Recife Pernambuco Brazil \\ asg@cin.ufpe.br
}

\author{
Fernando Moreira \\ IJP, REMIT \\ Universidade Portucalense \\ Porto Portugal \\ IEETA \\ Universidade de Aveiro \\ Aveiro Portugal \\ fmoreira@upt.pt
}

\begin{abstract}
Hybrid education or blended learning is an educational method that incorporates technological and online resources into regular classes, even in traditional learning environments. Spatial conditions influence social relations and the development of cultural bonds inside a building, which may affect changes in layout configuration and usability conditions.

The traditional configuration of most school classrooms must be reconsidered to allow changes in the educational paradigm. However, it is not clear which environmental aspects should be modified to improve performance in physical learning environments, especially to accommodate hybrid models in classrooms. This paper describes a participatory design process used to understand students' needs and perceptions in this era of digital and cultural changes. This study was carried out in a public secondary school in Northeastern Brazil and adopted qualitative research techniques to perform a participatory design exercise and understand the students' needs and problems. They collaborated in prototyping workshops to develop new classroom environment concepts.
\end{abstract}

The results suggest a set of guidelines for learning environment suitable for hybrid models that were developed using a participatory approach and linked learning activity modalities to environment quality criteria.

\section{CCS CONCEPTS}

- Social and professional topics $\rightarrow$ Computing profession • Applied computing $\rightarrow$ Education

\section{KEYWORDS}

Blended learning, classroom design, participatory design.

Permission to make digital or hard copies of all or part of this work for personal or classroom use is granted without fee provided that copies are not made or distributed for profit or commercial advantage and that copies bear this notice and the full citation on the first page. Copyrights for components of this work owned by others than ACM must be honored. Abstracting with credit is permitted. To copy otherwise, or republish, to post on servers or to redistribute to lists, requires prior specific permission and/or a fee. Request permissions from Permissions@acm.org.

TEEM'18, October 24-26, 2018, Salamanca, Spain (๑) 2018 ACM. ISBN $978-1-4503-6518-5 \ldots \$ 15.00$ http://dx.doi.org/10.1145/3284179.3284296

\section{ACM Reference format:}

T. S. Sarmento, A. S. Gomes and F. Moreira. 2018. In Proceedings of $6^{\text {th }}$ International Conference Technological Ecosystems for Enhancing Multiculturality, Spain, October 2018 (TEEM'18) (Salamanca, Spain, October 24-26, 2018), F. J. García-Peñalvo Ed. ACM, New York, NY, USA, 6 pages. http://doi.org/10.1145/3284179.3284296

\section{Introduction}

Most school environments have not evolved in the last few decades. This situation is not aligned with the actual pedagogical and technological innovations perceived in these spaces. The only difference is that new digital devices were incorporated to present the content - computers, projectors and tablets. In the classrooms, teaching activities keep the same traditional and centralized method: the teacher conducts the whole didactic process to transmit knowledge to students, which can include technological resources. "The last technological disruption in teaching happened more than 500 years ago. Until then, the role of the 'lecturer' had been clear - the root word being the Latin 'lectura', meaning to 'read' [1].

Innovative changes in schools should be accompanied by the design of flexible layouts to adapt learning environments to activities and people's needs. A culture of collaboration and a modern learning environment are expected to improve the contemporary learning process [2].

Student-centered practices involve the integration of three components: educational system (the whole), environment (place), teachers and students (people) 4. To put these in practice, teachers must be trained, and physical environments made appropriate.

The adoption of technologies requires changes in the role of students, teachers and staff, especially regarding: technological resources management; wireless network and mobile use permissions; the production, sharing and downloading of educational content; effective use of technology and continuous monitoring of its impact on students' results; changes in the built environments, facilities and equipment [3] .

This article describes the process of participatory classroom design and the adjustment required by hybrid educational practices. Section 2 discusses the relation between space and hybrid education practices as well as the use of new technologies and innovations for classroom space. Section 3 presents the research method used - participatory design involving high 
school students to develop new concepts for learning environments. Section 4 discusses the results, the elaboration of spatial concepts connected to hybrid education practices. In the last section, a final discussion is presented.

\section{Blended Learning and attempts to adapt classroom layout}

Hybrid, active and student-centered methodologies emerged in the progressive educational movement of late $19^{\text {th }}$ century, inspired by the theories of John Dewey, Jean Piaget, Lev Vygotsky and Maria Montessori [ $[5]$. These authors influenced education methods by providing experimental efforts and the study of natural and social environments. Their hypothesis is that the learning process is more effective when students are actively involved [6]. Content learning is more effective when students are connected to a wide possibility of practical experiences, in which the 'learning - doing' approach contribute much more than just listening to an expert talking [7]. This learning experience is important because it points to the autonomy skill, one of the most critical competence for a $21^{\text {st }}$ century student [8]. Hybrid education brings technological and online resources to both learning processes and environments. Its main characteristics are:

- Formal educational programs in which a student learns, at least in part, through online resources;

- Student effectively manages time, place, path and/or rhythm;

- Learning occurs both traditionally (where teachers conduct face-to-face learning) and partly online (ensuring continuity of content) $[9, \underline{10}]$.

Spatial conditions seem to influence the construction of social and cultural links by spatial configuration [11], consequently, the physical space can stimulate different types of social, cognitive and affective learning [12]. The characteristics of classroom spaces for hybrid education are being developed as learning systems evolve worldwide.

For decades, classroom layout had not been updated, in contrast with learning technological resources which followed autonomous learning trends. Contemporarily, a learning environment refers to a variety of physical locations, contexts and cultures in which students may learn [14], including out-of-school locations, libraries, urban spaces, parks or anywhere Information Communication Technology (ICT) devices may be used.

The use of technological resources provides an open and dialogic communication between teachers and students [15]. ICTs are real catalysts for people interaction because they permit new ways to achieve practical and theoretical learning, by merging face-to-face and online education [1]ㅡ. Hybrid education allows students to choose the time, pace and place they want to learn or work online - either in a traditional classroom or anywhere else [10].

By $2019,50 \%$ of all high school disciplines in the USA will be provided through online resources [9]. They recognize the importance of teacher's conduction and routines provided by schools, thus a full-time virtual learning will not totally replace classroom teaching and learning. Although they recently invested around 2 trillion dollars in education, problems in school design and construction continue to exist [ $\underline{3}]$.

Inadequate classrooms, the lack of equipment and unfriendly environmental conditions cause negative behavior in students and affect their relationship with teachers, requiring extra efforts to achieve individual or collective learning $[16,17]$. Currently, older school buildings hinder the emergence of $21^{\text {st }}$ century education regarding space flexibility and ICT usage. With an innovative design, the building can function as a catalyst for pedagogical changes [18].

\subsection{Hybrid educational models}

There are four models of hybrid education, each one with specific configurations and learning practices. They vary from the best adapted traditional formats to the most disruptive formats [9]:

- Rotation model: face-to-face and online activities in groups. They are rotated according to the teacher's goal or by time demarcation: station rotation; rotational laboratory; inverted classroom; individual rotation;

- Flex model: education is mainly online, and schools choose between personal, individual or group activities when necessary;

- À la carte model: online course or discipline. Students can incorporate it to the main face-to-face education;

- Enriched virtual model: low occurrence of face-to-face learning sessions and higher load of online activities.

Rotation models are considered suitable for conventional classrooms in elementary and middle schools. For these models, the architecture, furniture and school operations are different from a traditional classroom (where desks face a blackboard and teacher), which seems insufficient for dynamic learning where students are co-responsible for their learning process. Offering digital technology fosters interest and opens new ways to learn, produce and share content. Therefore, a well-designed learning space should give students a broader experience of learning modalities than expository classes. In dynamic learning systems, four different ways of learning are considered: campfire (learn with an expert); watering hole (learn with peers); cave (learn by introspection - individual study); life (learn by doing) [19]. By allowing these four types of learning modalities, students are given the benefit of a complete education [20], instead of traditional classrooms only designed for campfire mode (learn with an expert).

Recent successful experiences in reconfiguring learning environments highlighted the need to reformulate the classroom layout by adopting flexible and innovative solutions:

- Learning studio and learning suite layouts (two or more learning studios combined) without internal compartments, aiming to increase the impact on learning. Teachers are not alone with a single class, but the work is fully collaborative, joining two or even four classes in a single multidisciplinary space [3]; 
- An engaged learning model which reinforces the idea of flexibility of internal layouts. The furniture is flexible and increase the possibilities for spatial reconfiguration according to the dynamic necessity of the day [21] ;

- The layout model for learning environments developed by the Centre of Initiative in the Excellence of Teaching and Learning (CETL) [22] from the universities of Sussex and Brighton in the UK;

- The award-winning innovative solutions for Vittra Schools design in Denmark, by Rosan Bosch [2]ㅡ, which creates autonomous learning spaces and the design of constructive elements compatible with the collaborative educational method adopted;

- A smart classroom that proposes a configuration optimized for content presentation, free access to learning resources and the interactivity provided by the continuous use of ICT [24].

In many countries including Brazil, the biggest challenge with school infrastructure is the expense of great financial resources to reform and/or adapt a whole set of public schools. There are countless problems: the lack of maintenance, poor aesthetic quality and landscape aspects, even in new buildings. Additional existing problems involves the hiring and training of design professionals to solve these problems.

The present study aims to understand classroom users' needs (students and teachers) as current participants of blended learning methods. Their input guided a participatory design process for new learning environment concepts that could be implement in Brazilian public schools.

\section{Method}

The method is based on participatory design practices which give users the same value as experts on their own activities or experiences [25]. They are invited to participate in planning and prototyping techniques because they know their routine, needs and problems better than anyone.

The analyzed data resulted in the elaboration of guidelines compiled as the final product of a doctoral thesis in Design. The study is made available to other researchers, school directors or government education entities as suggestions for consulting, prior to the planning and building of new schools in Brazil.

\subsection{Data collection techniques}

Data was collected over five days at a selected school, gathering information from students and teachers on their self-reality perception. The research applied two techniques during observation: ethnographic observation and interviews. Data was registered in photographs, usage maps as well as dimensional and environmental checklists. After the observational stage, collected data was used to develop a prototype, in a participatory design process.

The quick ethnographic observation aimed to find patterns of learning activity in the analyzed school environments [26]. The goal was to collect data about how users deal with technology, perceive the learning environment, their use of active educational methods and analyze the activities developed in the built environment.

\subsection{Context and participants}

Cicero Dias State Technical School was inaugurated in 2006 and offers full time secondary education. Its mission is to create innovative learning and teaching methodologies, make use of ICTs, explore and discuss daily life and bring students closer to their surrounding reality. In 2017, there were 452 students enrolled in 08 classes. For this research, 33 students participated as volunteers.

\subsection{Prototyping concepts of future learning environments}

As a first step in the participatory design process, a brainstorming workshop allowed users to bring up their perception on the design of learning environments. Second, a prototyping technique desktop walkthrough [27] - used thumbnails to simulate scenarios for a classroom suitable for blended learning activities. Collected data was synthesized and used to generate final design concepts. Graphical representations and a final virtual-reality prototype were brought to discussion in focal groups with users. Finally, these last steps were used to evaluate the model.

\section{Results}

\subsection{Observation data}

The rooms in the selected school are organized by lesson content, where users move from one room to another for every new content on schedule. Despites the good technological school apparatus available to students, device use is highly controlled, mobile technology is poor, the wireless network unstable and room layouts are mainly designed for expository lessons. To use digital resources, students must move to a specific computer room. During group activities, moving furniture is difficult because space is insufficient, hindering dynamic or hybrid activities.

\subsection{Prototyping and evaluation with users}

The brainstorming results shown in Figure 1 highlight the need for a larger space for study and socializing in outdoor areas, windows opening to outside areas, more time for individual study and relaxing, better seats and chairs conditions, the use and availability of Internet connection and autonomy to use a mobile phone as an online search tool. 


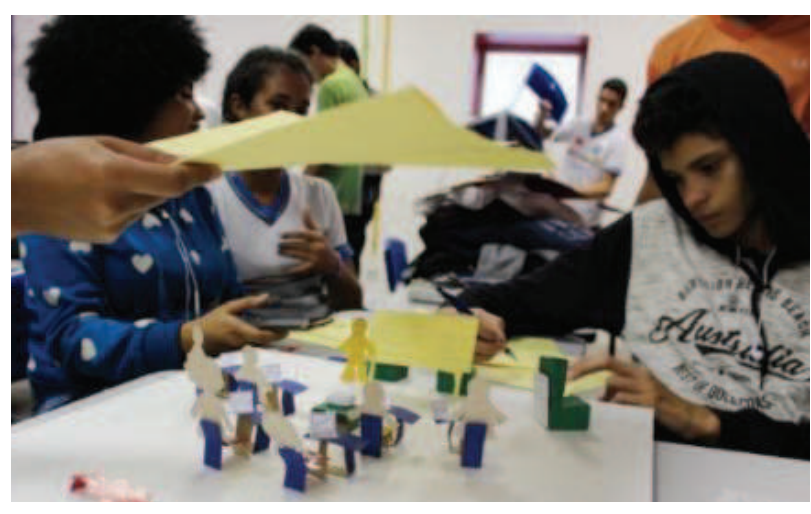

Figure 1: Students during a participative design workshop

During prototyping, the researchers obtained primary data on users' needs and used it to model a virtual reality prototype (Figure 2). The prototype was brought into discussion in focus groups with students, teachers and experts as the final step in the design process.

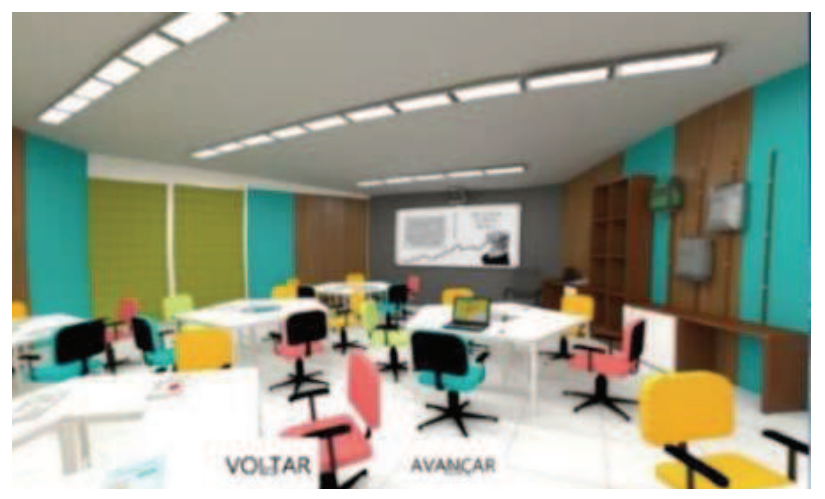

Figure 2: The virtual reality prototype used to obtain user evaluation about new concepts for learning environment

The main design concepts obtained for built environments suitable for hybrid rotation models relate to:

- Welcomes to release tense relations between teachers and students;

- Calmness and relaxation, to improve individual concentration and reading skills, especially in outdoor areas;

- Largeness and transparency, to improve accessibility, spatial and comfort conditions;

- Simplicity, brightness and joviality, enhanced by color appreciation, furniture flexibility, connection with outdoor spaces;

- Efficiency of technology provided by the management of digital and environmental resources;

- Usability, versatility and customization of conditions provided, along with a flexible spatial configuration required by the learning activity;
- Identity, familiarity and security, linked to an appropriate number of students in class, provide conditions to produce and share knowledge.

A good learning environment should accommodate four learning activity modalities [19]. This study therefore developed four categories of technical guidelines to adapt school environments to such modalities. Environment guidelines are: (1) built environment, (2) comfort conditions, (3) layout and furniture and (4) technology (Table 1). In order to adapt learning environments to hybrid education, the technology criteria were included as the main suggestion group.

Table 1: Guidelines for learning activities suitable for the hybrid learning model.

\begin{tabular}{|c|c|}
\hline $\begin{array}{l}\text { LEARNING } \\
\text { ACTIVITIES }\end{array}$ & GENERATED GUIDELINES \\
\hline $\begin{array}{l}\text { GLOBAL } \\
\text { CONDITI- } \\
\text { ONS }\end{array}$ & $\begin{array}{l}\text { Allow windows to view activities in the } \\
\text { classroom and outdoor spaces; } \\
\text { Ensure physical accessibility to all school } \\
\text { environments, including restrooms, sports } \\
\text { and service areas; } \\
\text { Install bathrooms of domestic configuration } \\
\text { in the vicinity of the rooms, avoiding long } \\
\text { walks to collective bathrooms without } \\
\text { teacher supervision; } \\
\text { Allow color personalization and graffiti on } \\
\text { wall boards, favoring joviality, reception } \\
\text { and a sense of social identity; } \\
\text { Allow removable divisions between rooms } \\
\text { to allow size changes - larger spaces for } \\
\text { large groups and smaller spaces to } \\
\text { accommodate small study groups; } \\
\text { Allow moments for social interaction in } \\
\text { pleasant eating or reading areas with tables } \\
\text { for groups and comfortable light chairs; } \\
\text { Large windows to outdoor areas, natural } \\
\text { light and ventilation, while protecting these } \\
\text { elements from unpleasant climatic factors - } \\
\text { direct natural light, temperature and } \\
\text { excessive external noise; } \\
\text { Provide individual lockers for permanent } \\
\text { use, which may contain backpacks, books } \\
\text { and other personal belongings; } \\
\text { Maintain cleaning, maintenance, painting, } \\
\text { furniture and digital equipment in good } \\
\text { conditions. }\end{array}$ \\
\hline \multirow{3}{*}{$\begin{array}{l}\text { CAMPFIRE } \\
\text { (Learning } \\
\text { with an } \\
\text { expert) [1] }]\end{array}$} & $\begin{array}{l}\text { Built Environment } \\
\text { Install access doors at the back of the room, } \\
\text { avoiding the disruption of students' } \\
\text { attention to the blackboard }\end{array}$ \\
\hline & Comfort conditions \\
\hline & $\begin{array}{l}\text { Provide adequate visibility and audibility } \\
\text { conditions for the content being displayed } \\
\text { [28] } \\
\text { Install partitions / acoustic panels - } \\
\text { alternating absorbers and reflectors to } \\
\text { improve performance; }\end{array}$ \\
\hline
\end{tabular}




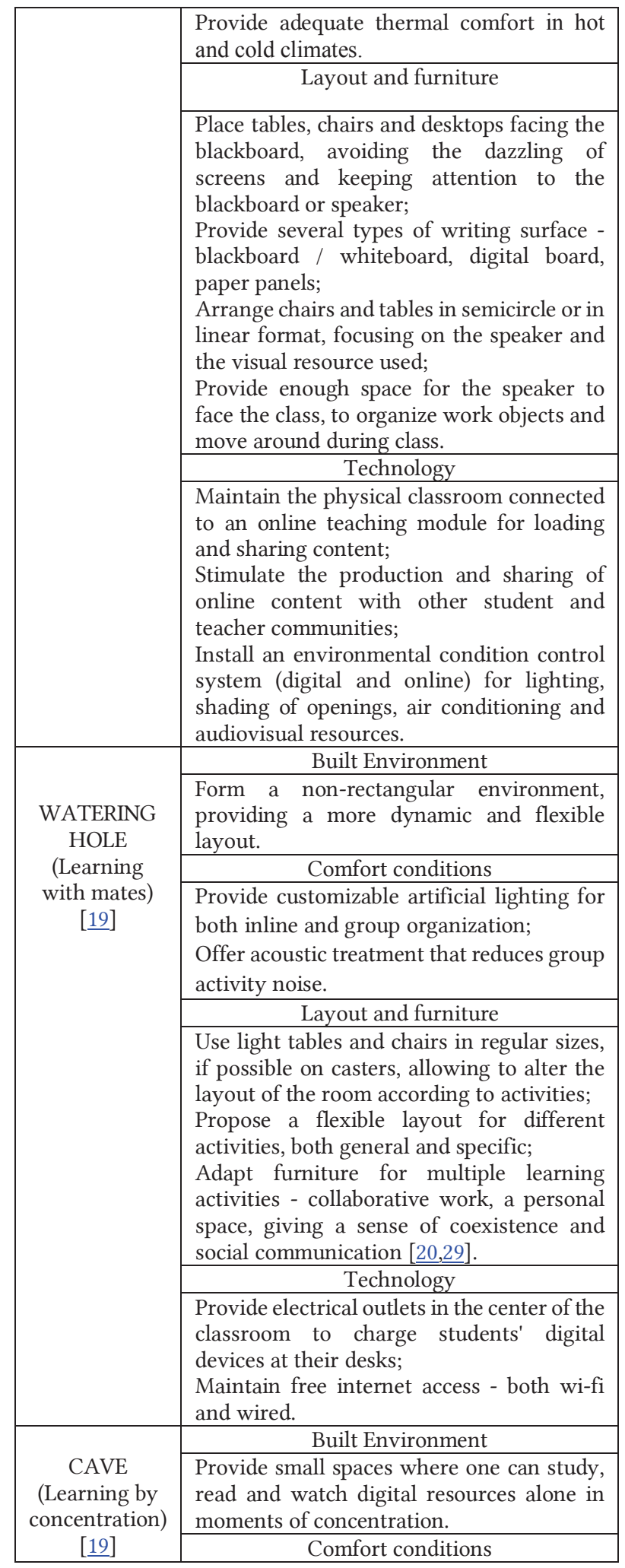

\begin{tabular}{|c|c|}
\hline & $\begin{array}{l}\text { Provide task lighting and directional } \\
\text { lighting for reading activities on armchairs } \\
\text { and at individual tables. }\end{array}$ \\
\hline & Layout and furniture \\
\hline & $\begin{array}{l}\text { Provide chairs with adjustable seat, feet and } \\
\text { arms support, if possible with casters; } \\
\text { Provide soft cushions and surfaces to sit on } \\
\text { the floor, benches, next to a terrace or } \\
\text { outdoor spaces. }\end{array}$ \\
\hline & Technology \\
\hline & $\begin{array}{l}\text { Allow internet access on personal devices } \\
\text { such as laptops and cell phones for } \\
\text { educational purposes. }\end{array}$ \\
\hline & Built Environment \\
\hline $\begin{array}{c}\text { LIFE } \\
\text { (Learning by } \\
\text { doing) [19] }\end{array}$ & $\begin{array}{l}\text { Provide time to discuss school community } \\
\text { issues; } \\
\text { Provide alternative spaces to carry out } \\
\text { practical work - balconies, patios, gardens } \\
\text { and public squares in surrounding areas. }\end{array}$ \\
\hline & Comfort conditions \\
\hline & $\begin{array}{l}\text { Integration with local climatic, cultural and } \\
\text { territorial conditions for the execution of } \\
\text { practical contextual work. }\end{array}$ \\
\hline & Layout and furniture \\
\hline & $\begin{array}{l}\text { Allow outdoor personal accommodation } \\
\text { conditions - tables, chairs and climate } \\
\text { protection. }\end{array}$ \\
\hline & Technology \\
\hline & $\begin{array}{l}\text { Maintain an information and knowledge } \\
\text { network inside and outside the school with } \\
\text { information exchange and online learning. }\end{array}$ \\
\hline
\end{tabular}

\section{Conclusions}

The participatory design process highlighted the experiences of users in existing learning environments, as well as the need for professionals and directors to rethink how technology is being used in current Brazilian school environments. Users are rarely questioned or heard on their spatial experiences of collective environments and hardly ever consulted on the development of architectural projects in Brazil. Therefore, the data herein is relevant for the consolidation of environmental research based on social participation.

Learning environments in both public and private schools are often adapted to the use of a specific group or period, and inadequately designed to support multiple forms of learning.

This research elaborated guidelines for learning environments, associating multiple learning activities to performance criteria for built environment, comfort conditions, layout, furniture and technology. These guidelines were based on primary data research, with users and specialists, as well as bibliographic references, in order to reinforce the trends in hybrid learning environment design and adapt existing ideas to Brazilian cultural and climatic conditions.

In Brazil, it is important to consider the brazilian bioclimatic map (Zoneamento Bioclimático Brasileiro) [30] as the technical normative for efficient use of natural climatic resources. This map categorizes eight different zones, in which the combination of air 
temperature and humidity conditions form similar area characteristics. In each architectural project, the climate characteristics of the locality must be respected, to achieve most efficient use of environmental resources when building is in use. This map recommends guidelines for: ideal size of windows (for better ventilation), strategies for windows' shade against excessive sunlight, types of external walls and roofs and passive thermal conditioning strategies.

As important as climate adequacy, in each one of the five Brazilian geographical regions there are own cultural and social expressions. They should be considered in education system, especially when there is a trend in make connections between life and school practices. The addition of flexibility concepts to school environments may support community needs and desires, respecting their folk and artistic expressions, as well as their forms of language and social behavior.

Future research projects aim to refine studies on collaborative and autonomous learning, the teacher/students' relationship in hybrid models, school space for content production and sharing among students and society. In conclusion, the results corroborate the literature review on learning environment reconfiguration.

\section{REFERENCES}

[1] R. Buckley, 2015. Why the education sector is ripe for digital disruption, http://www.i-cio.com/management/insight/item/why-education-sector-isripe-for-digital-disruption.

[2] M. Pedaste, K. Pedaste, K. Lukk, P. Villems, \& R. Allas. (2014). A model of Innovation Schools: Estonian case-study. Procedia - Social and Behavioral Sciences, 112, 418-427

[3] P. Nair, R. Fielding, J. Lackney, 2013. The Language of School Design. Design Patterns for 21st Century Schools (3rd ed.). Designshare.com, Minneapolis, USA.

[4] B. Acat, I. Dönmez (2009). To compare student centred education and teacher centred education in primary science and technology lesson in terms of learning environments. Procedia - Social and Behavioral Sciences, v. 1(1), 1805-1809.

[5] J. C. Libâneo, 1990. Democratização da Escola Pública. Loyola, São Paulo, Brazil.

[6] R. Gerver, 2010. Creating tomorrow's schools today. Education: our children, their future. Bloomsbury Publish, London, UK, New York, USA.

[7] G. Gibbs, 1988. Learning by doing: A guide to teaching and learning methods. FEU.

[8] World Economic Forum. 2016. New Vision for Education: Fostering Social and Emotional Learning Through Technology. http://www3.weforum.org/docs/WEF_New_Vision_for_Education.pdf.
[9] B. Horn, M. Staker, M. Heather. 2015. Blended: Usando a Inovação Disruptiva para Aprimorar a Educação. Penso, VitalBook file.

[10] L. Bacich, N. Tanzi, F. M. Trevisani, 2015. Ensino Híbrido: Personalização e Tecnologia na Educação. Penso, VitalBook file.

[11] C. H. Taralli, 2004. Espaços de Leitura na Escola: Salas de Leitura, Bibliotecas Escolares. Boletim Salto Para o Futuro. 31-39. MEC, Rio de Janeiro, Brazil.

[12] H. Sanoff, 2001. A Visioning Process for Designing Responsive Schools. USA.

[13] B. J. Fraser, (1994). Classroom and school climate. D. Gabel (Ed) Handbook of research on science teaching and learning, 493-541. Macmillan, New York, USA.

[14] C. Coll, C. Monero, 2010. Psicologia da educação virtual: aprender e ensinar com as tecnologias da informação e da comunicação. Artmed, Porto Alegre, Brazil.

15] K. Mackey, M. B. Horn, 2009. Florida virtual school: building the first statewide, internet-based public high school. Clayton Christensen Institute.

http://www.christenseninstitute.org/wp-content/uploads/2013/04/Florida-VirtualSchool.pdf.

[16] M. A. Powell, 2015. Reacting to Classroom Design: A Case Study of How Corrective Actions Impact Undergraduate Teaching and Learning. Doctoral Thesis, Lesley University, USA.

[17] L. Baker, 2011. What School Buildings Can Teach Us: Post-Occupancy Evaluation Surveys in K-12 Learning Environments. Master Thesis, University of California, Berkeley, USA

[18] D. G. Oblinger, 2006. Learning Spaces. Educause e-book.

[19] D. Thornburg, 1999. Campfire in Cyberspace. Starsong, Lake Barrington, IL, USA.

[20] P. Nair, 2014. Blueprint for tomorrow. Redesigning Schools for StudentCentered Learning, Harvard Education Press, Cambridge, USA.

[21] Cannon Design. vs furniture, Bruce Mau Design. 2010. The third teacher: a collaborative project. Abrams, New York, USA.

22] Higher Education Funding Council for England - HEFCE. 2010. Designing Spaces for Effective Learning. JISC Development Group, University of Bristol, UK, www.jisc.ac.uk/eli_learningspaces.html.

[23] Archdaily Homepage. 2011. Vittra Telefonplan/ Rosan Bosch. http://www.archdaily.com/202358/vittra-telefonplan-rosan-bosch.

[24] P. Asaro, (2000). Transforming society by transforming technology: the science and politics of participatory design. Accounting, Management and information Technologies, vol. 10, 257-290.

[25] M. J. Muller, 2003. Participatory design: the third space in HCI. Handbook of HCI. Lawrence Erlbaum, New York, USA.

[26] D. R. Millen, (2000). Rapid ethnography: time deepening strategies for HCI field research. In: Proceedings of the 3rd conference on Designing interactive systems: processes, practices, methods, and techniques, pp. 280-286. ACM, New York.

[27] M. Stickdorn, J. Schneider (orgs). 2014. Isto é Design Thinking de Serviços. Fundamentos, ferramentas, casos. Bookman, Porto Alegre, Brazil.

[28] L. Gee, 2006. Human-centered design guidelines. In: D. Oblinger (ed.) 2006. Learning Spaces, 10.1-10.13. http://www.educause.edu/learningspacesch10.

[29] G. McVey, 1996. Ergonomics and the learning environment. In: D. Jonassen (ed.) 1996. Handbook of Research for Education Communications and Technology. New York: Macmillan, USA.

[30] Associação Brasileira de Normas Técnicas (2003). NBR 13507-003. Desempenho térmico de edificações Parte 3: Zoneamento bioclimático brasileiro e diretrizes construtivas para habitações unifamiliares de interesse social. Rio de Janeiro, Brazil 